\title{
CORRUPÇÃO E MORTE DA POLÍTICA: ANÁlise de UMA PATOLOGIA SOCIAL
}

\section{Orlando Lyra de Carvalho Jr. ${ }^{1}$}

\begin{abstract}
Resumo
Apartir do conceito moderno de corrupção política, que define esse fenômeno como sendo a utilização indevida do poder público para ganhos privados, o artigo aborda a transformação conceitual que a noção de corrupção sofreu desde a Antigüidade Clássica. Por meio de uma análise foucauldiana de aspectos centrais do processo histórico-político, que tornou possível a transposição do termo interesse do campo meramente econômico para formas e noções centrais da organização política contemporânea, chega-se à conclusão que, se aplicado ao pé da letra, o conceito moderno de corrupção representaria a morte da política e o caminho mais seguro para o totalitarismo.

Palavras-chave: Corrupção. Interesse. Foucault. Biopolítica. Lei. Disciplina.
\end{abstract}

\begin{abstract}
s
Using the modern concept of political corruption, defined as the undue utilization of public power for private gains, this article examines the conceptual transformation of that the notion of corruption has undergone since Classical Antiquity. Through a Foucauldian analysis of central aspects of the historical-political process, which makes possible the transposition of the term interest from the merely economic field to central forms and notions of contemporary political organization, we
\end{abstract}

${ }^{1}$ Mestrando em Ciências Sociais - UFJF. Contato: lyradecarvalho@yahoo.com 
reach the conclusion that, if applied literally, the modern concept of corruption represents the death of political and the surest path to totalitarianism.

Keywords: Corruption. Interest. Foucault. Biopolitics.

\section{INTRODUÇÃO}

Pretendemos, neste artigo, analisar alguns aspectos do fenômeno da corrupção política na perspectiva daquilo que Michel Foucault chamou de práticas e relações de poder (2000, p.21), isto é, sob o ângulo da anatomia dos bábitos e costumes políticos (1994, p. 208) que alimentam a corrupção em geral.

Se considerada sob esse ângulo, nota-se logo que a corrupção se caracteriza pela persistência e capacidade de renovação como fenômeno recorrente no mundo político. Tal persistência, a nosso ver, foi bem descrita pelo sempre metafórico presidente Lula: "A corrupção é como petróleo, quanto mais se investiga, mais aparece"2.

Talvez seja por isso que a corrupção, quão novo fênix, está sempre pronta a ressurgir da poeira dos escândalos e a sobreviver intacta às vagas da denúncia. Muitos chamam isso de impunidade. Realmente, sob a perspectiva jurídico-legal, o combate à corrupção, hoje, tem muito de espetáculo e pouco de condenações, bastando para isso constatar que, até o presente momento, político algum foi condenado por corrupção pelo Supremo Tribunal Federal ${ }^{3}$. Por exemplo, das 245 pessoas presas em dez operações realizadas pela Polícia Federal entre 2003 e 2004, 64 foram julgadas, mas só duas continuam na cadeia ${ }^{4}$. Esse fato inspirou a comparação histórica de José Murilo de Carvalho: "Getúlio saiu da vida para entrar na história. Hoje, os corruptos saem da história para entrar na vida"'5.

${ }^{2}$ Folha de S. Paulo, 8 de junho de 2007.

${ }^{3} 0$ escândalo político conhecido como mensalão, definido pelo procurador-geral da República, Antonio Fernando Souza, como resultado da ação de uma "organização criminosa" chefiada pelo ex-ministro José Dirceu, foi apreciado pelo Supremo Tribunal Federal, que aceitou a denúncia da Procuradoria Geral da República, negando, entretanto a acusação de peculato (apropriação indevida de dinheiro ou bens públicos para proveito próprio ou de terceiros, art. 312 do Código Penal) a José Dirceu, Delúbio Soares (ex-tesoureiro do PT), Sílvio Pereira (ex-secretário do PT) e do deputado José Genoino (ex-presidente do PT).

${ }^{4}$ Veja, 15 de agosto de 2007.

${ }^{5}$ Folha de S. Paulo, 3 de junho de 2007. Ver também, A boa vida dos mensaleiros, Veja, 15 de agosto de 2007. 
Atualmente, a corrupção funciona em redes, é muito mais organizada e profissional do que outrora, anda de braços dados com o crime organizado, o qual, por sua vez, encontra-se alojado nas entranhas do aparelho do Estado brasileiro: "Não existe crime organizado sem a participação de um agente público e político", afirmou Gilson Dipp, ministro do Superior Tribunal de Justiça ${ }^{6}$.

Essa ocupação da máquina estatal por agentes públicos (nos três Poderes da República e nos vários níveis da Federação Brasileira), os quais lideram grupos e organizações criadas para pilhar o erário público, já permite, por um lado, o desenvolvimento do conceito de Estado delinqüente (GAIO, 2007) como nova modalidade de crime.

Por outro lado, ainda do ponto de vista jurídico, a complexidade do crime de corrupção, que se caracteriza pela violação ou dano a bens jurídicos difusos, muitas vezes torna difícil a especificação da vítima, sobretudo nos crimes do colarinho branco (LIVIANU, 2006, p. 148). Mas ninguém duvida de que o crime organizado, e até o terrorismo, são ajudados ou sustentados pela corrupção.

Há três anos, dois aviões russos explodiram em um atentado terrorista. As duas mulheres que entraram nos aviões e mataram quase uma centena de pessoas pagaram pouco mais de 50 dólares cada uma para conseguir embarcar sem serem revistadas pela segurança do aeroporto.

Segundo o chefe do Programa Global das Nações Unidas contra a Corrupção, Stuart Gilman, "a corrupção não é um crime sem vítimas. Na verdade, as vítimas podem ser contadas aos milhões".

\section{CONCEITO DE CORRUPÇÃO}

A maior parte dos pesquisadores concorda que, na noção de corrupção, sempre se encontra a idéia de uma "subversão do público pelo privado" (HEIDENHEIMER, JOHNSTON \& LEVINE, 1989; JOHNSTON, 2005; ROSEACKERMAN, 1999; HUNTINGTON, 1968).

Segundo Heidenheimer, Johnston e LeVine, existem na atualidade três abordagens principais que procuram definir a noção de corrupção política: uma abordagem administrativa (public office centered), na qual a corrupção

${ }^{6}$ Folha de S. Paulo, 23 de abril de 2007.

${ }^{7}$ Veja, 8 de agosto de 2007. 
é vista como um desvio das normas de administração pública; uma abordagem mercadológica (market centered), em que corrupção é vista como a busca de vantagens pessoais por parte dos servidores públicos (rent-seeking activity); e uma abordagem centrada nos interesses públicos (public interest centered), a qual salienta as ações que implicam em dano para os interesses públicos. Em todas elas, encontra-se a idéia de que opúblico é de algum modo subvertido pelo privado (HEIDENHEIMER, JOHNSTON \& LEVINE, 1989).

Com relação aos tipos de interesse, podemos dizer que existem dois: 0 público e o privado. Como corolário de tal divisão, nasce o dever de o agente público abstrair de seus interesses privados a fim de agir conforme a ética pública.

Tal conceito merece uma análise mais detalhada. Trata-se de saber por que o conceito de corrupção veio a representar a idéia de subversão do interesse público por interesses privados.

Isso é tanto mais necessário quanto o conceito tradicional de corrupção (do grego, diaphtheirein) trazia consigo a noção de decadência, de regressão, de não virtuoso. ${ }^{8}$ Ou seja, a idéia de que, por meio da doença (corrupção), vício ou qualquer outra razão, a capacidade de se alcançar o bem e a virtude decrescia (BRATSIS, 2006, p. 57).

Em contraste, o conceito moderno de corrupção deixa de lado a noção de que algo é bom em si (e deve ser buscado) em oposição a algo que é mal em si (e deve ser evitado), para substituí-la pela idéia de dois tipos de interesses ${ }^{9}$ que são bons em si: 0 interesse público e o privado.

De Max Weber (1968) e de Albert Hirschman (1977), passando por Michel Foucault (1979), deriva uma linha de pensamento que se esforça em demonstrar como os interesses privados, sobretudo em sentido econômico, transformaram-se em algo positivo com a emergência do capitalismo.

Para Hirschman, foi a prevalência do capital financeiro que engendrou, no limiar da era burguesa, um novo vocabulário responsável pela transposição do termo interesse, do campo meramente econômico, para formas e noções centrais da organização política contemporânea (MAUSS, 1990, p. 76).

\footnotetext{
${ }^{8}$ Derivado do grego, areté, ou seja, a virtude como habilidade entendida naturalmente (REALE \& ANTISERI, 2004).

${ }^{9}$ Sobre a atuação dos interesses na vida econômica e política moderna, ver também Przeworski (1995).
} 
É nesse contexto que Hirschman comenta a noção de corrupção em Maquiavel e nota que o termo sofreu uma mutação semelhante: "A idéia de corrupção teve uma trajetória semântica similar. Em seus escritos, Maquiavel usa o termo emprestado de Polybius, corruzione, no sentido de deterioração da qualidade do governo. Até o século XVIII, a expressão ainda foi usada na Inglaterra nesse mesmo sentido, embora incluísse também a idéia de propina. Depois disso, o sentido financeiro da expressão expulsou por completo o sentido original" (HIRSCHMAN, 1977, p. 40).

\section{ForMAS DE INTERESSE E FORMAS DE GOVERNAMENTALIDADE}

Foucault analisa a questão dos interesses ao tratar das artes de governar ou governamentalidade: esta diz respeito à gestão das coisas e das pessoas, a um problema de governo, entendido no sentido de condução de populações. É 0 problema do governo como gestão das condutas que forma o objeto das diferentes formas de governamentalidade política, especificadas por Foucault nos cursos de 1978 e 1979.

A primeira dessas formas, situada por Foucault entre os séculos XVI e XVII, é a razão de Estado, cujo problema central é definir o tipo de racionalidade que deve orientar o governo dos homens realizado pelo poder soberano e definir os objetos sobre os quais se assentará tal poder.

Em resumo, pode-se dizer que a razão de Estado é um tipo de racionalidade da prática governamental que encara o Estado segundo dois traços fundamentais: o Estado é ao mesmo tempo um dado e um objeto a ser construído. Na primeira aula de Naissance de la biopolitique, Foucault (1979) comenta que, nesse tipo de governamentalidade, o Estado é algo que já existe, mas não suficientemente. Por isso, é organizado por uma política interna baseada em princípios ilimitados de intervenção.

Foi na segunda metade do século XVIII que, de acordo com Foucault, operou-se uma ruptura conceitual, uma transformação importante nas formas de governamentalidade no ocidente. Trata-se do surgimento de um princípio de limitação da arte de governar no que concerne às medidas de política interna adotadas pelos Estados. A intervenção do Estado sobre a vida e as atividades dos indivíduos deverá, a partirde agora, obedecer a um princípio de limitação intrínseco. 
0 instrumento intelectual de tal transformação foi a economia política ${ }^{10}$, e o seu resultado foi uma nova forma de governamentalidade chamada liberalismo.

No liberalismo surge o mercado como lugar e mecanismo de formação da verdade sobre o Estado e sobre a função de governar. 0 mercado é visto por Foucault como um locus de veridicção ${ }^{11}$ da prática governamental. Ao Estado cabe deixar o mercado atuar com a menor intervenção possível a fim de que ele possa formular suas verdades e propô-las como regra à prática governamental.

Sendo o mercado o ponto de fixação da nova governamentalidade, a ela já não caberá dar conta do interesse do Estado referido exclusivamente a si mesmo, ou seja, referido somente à sua riqueza, a seu crescimento, à sua população. Àarte de governar liberal caberá o ordenamento do conjunto de interesses que se cruzam no interior do Estado. Será o jogo complexo entre interesses individuais e coletivos, entre utilidade social e lucro econômico, que caberá a tal governamentalidade organizar.

Portanto, o traço mais importante da governamentalidade liberal é assegurar o jogo complexo dos interesses e garantir a liberdade necessária para que tal jogo se desenrole. É nesse ponto que Foucault começa a discutir, em Naissance de la biopolitique, (FOUCAULT, 1979, p. 67) os mecanismos de segurança como o princípio de cálculo para a fabricação das liberdades necessárias à arte de governar liberal.

Tal governamentalidade tem seu funcionamento atrelado à necessidade de determinar exatamente em que medida, e até que ponto, os interesses individuais, as liberdades individuais, vão constituir ou não um perigo para 0 interesse de todos. A governamentalidade liberal vê-se constrangida a garantir que a liberdade dos processos econômicos não se torne umperigo para as liberdades individuais.

Nessa perspectiva, entende-se que o jogo de interesses no liberalismo só poderá se manter puro ou livre de corrupção se houver mecanismos de segurança que garantam a separação das duas esferas de interesse, a pública e a privada.

\footnotetext{
${ }^{10}$ Economia política aqui entendida não só como processo econômico, mas sobretudo como programação estratégica acerca da atividade e do comportamento dos indivíduos, como criadora do homo economicus.

${ }^{11}$ Neologismo empregado por Foucault para realçar as relações entre o saber (veritas) e poder (dictum).
} 


\section{REGRAS DE PURIFICAÇÃO}

Com base nesses pressupostos, pode-se levantar então a seguinte pergunta: Como duas coisas boas em si, os interesses público e privado, uma vez misturadas, podem constituir algo mal, isto é, corrupto?

Uma possível resposta a tal questão seria trabalhar a idéia de corrupção como algo fora-de-lugar (DOUGLAS, 1966). Por exemplo, um par de sapatos no seu devido lugar seria considerado limpo (não corrupto), mas uma vez posto em cima de uma mesa de jantar seria considerado sujo (corrupto).

Poder-se-ia inferir, então, que tanto os interesses públicos quanto os privados são bons ou não-corruptos na medida em que se mantenham em seus devidos lugares. A contaminação do público pelo privado surge precisamente quando se verifica a promiscuidade de ambas as esferas. Políticos e a política ela mesma tornar-se-iam corruptos por haverem transgredido a separação categórica entre o público e o privado.

A concepção moderna de corrupção é, portanto, muito mais próxima da idéia de adulteração do que da deterioração da capacidade para o bem (diaphtheirein): um vinho se adultera (corrompe) pela presença de outra substância, como a água, por exemplo.

Percebe-se, assim, que tanto no sentido clássico quanto no moderno, há uma distinção normativa do que seja corrupção política ao se estabelecerem condutas desejáveis e indesejáveis. Para os gregos, características específicas do cidadão, dos governantes ou do regime são postas em contraste com outras características consideradas más ou indesejáveis de acordo com uma certa realidade. Já os modernos estabeleceram uma divisão estrita entre o público e do privado. Qualquer fenômeno que atente contra tal divisão é considerado corrupção política.

\section{Reagan e Clinton}

Podemos tomar o caso do ex-presidente dos Estados Unidos, Ronald Reagan (1981-1989), que sofria de Alzheimer, para melhor entendermos esses dois conceitos e contrastá-los entre si. Supondo que, nos últimos anos do mandato de Reagan, a doença tivesse evoluído para um estágio debilitante de sua capacidade de tomar decisões, ter-se-ia um caso típico de diaphtheirein, corrupção no sentido tradicional, mas de nenhum modo um caso de corrupção em sentido moderno. 
Agora imaginemos o caso dos escândalos políticos do presidente Bill Clinton (1993-2001): sabe-se que ele costumava convidar ricos contribuintes de campanha para suntuosos coffee breaks na Casa Branca, e que até a cama do ex-presidente Abraham Lincoln (1861-1865) era alugada como forma de fund raising político (cem mil dólares por noite).

Obviamente, o fato de se tomar café ou de se dormir numa cama jamais poderia ser considerado ato de corrupção política em sentido clássico. Já no sentido moderno, sim. Por quê? Simplesmente porque essas atividades com fins privados foram realizadas em lugarpúblico, por um agente público, o qual, indevidamente, permitiu a contaminação do espaço público pelos interesses privados.

Se os mesmos fatos tivessem ocorrido na casa de campo dos Clintons, ou na cama de Hillary, nada teria acontecido, nenhum requerimento de processo de impeachment teria sido votado (e negado) pelo Congresso dos Estados Unidos. Portanto, o mesmo café, as mesmas pessoas, as mesmas quantias vultosas de dinheiro, nada disso teria sido considerado ato de corrupção política.

\section{SePARAÇÃo CATEGÓRICA E LEGITIMAÇÃO POLÍTICA}

Essa diferença entre as duas noções de corrupção política - o bem em si e o fora-de-lugar - traz, por sua vez, consequiências significativas.

Por um lado, a noção de domínio público, construída a partir da separação categórica das duas formas de interesse, o público e o privado, desempenha um papel fundamental na legitimação política da sociedade burguesa. É preciso legitimar os interesses privados das classes dominantes como se fossem de interesse público. Para isso, o agente público precisa agir no domínio público, como se fosse destituído de qualquer motivação ou interesse privado. Em assim procedendo, ele não só reafirmaria a pureza de sua conduta, ao manter a separação categórica entre o público e o privado, mas também legitimaria a dominação política do Estado burguês.

Por outro lado, a divisão entre o público e o privado torna-se um valor em si, uma qualidade imanente a todas as sociedades, o padrão de normalidade, o que lhe confere uma suposta naturalização histórica. É este pressuposto hegemônico que constitui o padrão segundo o qual se classificam os níveis de corrupção nos ordenamentos políticos modernos (JOHNSTON, 2005). 


\section{A CRIAÇÃo SOCIAL do NORMAL E dO PATOLÓGICO}

A questão central agora é saber como as sociedades burguesas vieram a construir e regular os conceitos de normalidade e anormalidade, e por conseqüência de corrupção e não-corrupção, no que diz respeito à distinção do público e do privado.

Michel Foucault, em sua História da Loucura (2002), mostra como o normal é socialmente construído pela produção do patológico. Portanto, o normal, tanto no caso da corrupção política, quanto nas doenças mentais, é um conceito negativo. E como se conhece o patológico? Há normas que indicam 0 que é patológico. Normal deriva do latim norma. 0 normal é aquilo que segue a norma. No caso da corrupção política, o normal seria aquilo que não violasse as regras que regulam a pureza ou a separação das categorias público e privado.

E o que é a norma? Foucault trabalha com a idéia de umpoder, que antes de ser inibidor, seria produtor de individualidades, daquilo que ele chama de um "tecido de hábitos e práticas", o qual ele denomina de norma.

Portanto, norma é um critério que deve ser observado, uma medida que permite que se separem, no interior de um grupo determinado, duas categorias ou dois estados de indivíduos: os indivíduos normais, aqueles que se identificam com o perfil estabelecido por essa medida, e os indivíduos anormais, isto é, aqueles que, de algum modo, se afastam de tal perfil. A função da normalização consistiria em tornar as pessoas, os gestos, os atos, conforme o modelo da norma. Percebe-se, aqui, uma anterioridade da norma nesse tipo de normalização ou normação (normation), no francês (FOUCAULT, 1972-73, p. 210).

Nem os normais nem os anormais encontram-se fora desse critério de separação, ou seja, a norma. 0 que os diferencia não é uma natureza ou essência, mas um estado ou posição, em termos de coincidência ou não-coincidência, de cada um em relação à norma.

François Ewald oferece uma síntese dessas idéias de Foucault ao definir a norma como "um princípio de comparação, uma comparabilidade, uma medida comum, que se institui na pura referência de um grupo a si próprio, a partir do momento em que só se relaciona consigo mesmo, sem exterioridade, sem verticalidade" (EWALD, 1993, p. 86). 


\section{DA NORMA AO BIOPODER}

Mas para se entender melhor a idéia de norma em Foucault, é preciso compreender também a noção de poder e em que contexto tais noções foram desenvolvidas. É no interior da analítica do poder que Foucault desenvolve sua crítica às noções de poder predominantes no pensamento político ocidental. Isso não significa dizer que em Foucault haja uma teoria do poder, a qual suporia de algum modo a existência de um objeto de poder, uma estrutura determinada de poder. Pelo contrário, sua analítica do poder não pressupõe uma essência chamada poder, nem procura definir o poder, mas se limita aperceber diferentes situações estratégicas a que ele chama de poder (DAU, 2004, p. 91).

Portanto, o poder não é uma coisa, uma instituição, nem uma estrutura dotada de potência, mas apenas um nome dado a uma situação estratégica complexa numa determinada sociedade (FOUCAULT, 1997, p. 89).

Na analítica do poder, Foucault trata de refutar as principais versões de um modelo a que se pode chamar de substancial ou essencialista do poder, ou seja, o modelo que entende o poder como uma coisa. A esse modelo, a que ele denomina em termos gerais de jurídico-discursivo, suas análises opõem o modelo da normalização, quer dizer, um modelo em que o poder será pensado enquanto estratégia.

São as duas principais versões do modelo jurídico-discursivo de poder que constituem o objeto de suas críticas nos trabalhos $A$ vontade de saber e Em defesa da sociedade. 0 ponto de chegada comum dessas críticas será a abertura para as análises acerca de uma novaface dos mecanismos de normalização: a biopolítica, o biopoder ou a arte de governar.

o biopoder encerra uma forma de normalização diferente da normalização disciplinar. Nos mecanismos de poder da biopolítica, a normalização já não se configura como disciplina dos corpos dispostos no interior de certas instituições (prisão, hospital, escola etc), mas como o resultado de mecanismos de regulação e de segurança, que atuam sobre os processos do dia-a-dia das populações.

Uma das versões do modelo jurídico-discursivo do poder é aquela em que este aparece como algo que reprime e que impõe interdições. Seria a identificação do poder à repressão, em suas mais variadas formas. Pode-se dizer que a matriz teórica que melhor expressa essa concepção é o pensamento marxista, em que o poder tem por forma de atuação principal a opressão organizada e exercida pelas classes dominantes. 
A outra versão (liberal) é aquela em que o poder se confunde com a ordem, instaurada pela lei civil, decorrente de um Estado legítimo. Tal concepção, por sua vez, remonta ao pensamento dos filósofos contratualistas, em que a lei constituise na manifestação essencial de poder.

Em oposição à versão que considera o poder como uma instância repressiva, A vontade de saber procura mostrar que o poder não reprime nem interdita, mas incita e produz. Ao contrário da versão que vê no poder o veículo da instauração da paz social e da ordem, por meio da lei, Em defesa da sociedade procura pensar o poder enquanto guerra perpétua.

A partir destas duas vias críticas que faz incidir sobre as concepções de poder dominantes no pensamento ocidental, Foucault chega a uma concepção de poder que o entende enquanto um conjunto de mecanismos que têm no cotidiano das pessoas seu ponto de incidência mais importante.

\section{NORMA E LEI}

Em relação ao conceito de lei, como aliás em inúmeros outros temas, o pensamento de Foucault realiza uma apropriação em que a preocupação central não é com o conceito de lei propriamente dito, mas algo diverso. É a norma, e não a lei, aquilo que mais interessa a Foucault. Seu objetivo não é explorar a lei em si, mas a dimensão da normatividade da lei enquanto esta possa estar implicada com os mecanismos daquilo que Foucault chama de normalização em um plano de análise que prioriza as práticas. ${ }^{12}$

Por exemplo, em A Vontade de Saber e Em Defesa da Sociedade, há um conjunto de referências diretas e insistentes à lei, quando Foucault intenta estabelecer as diferenças entre dois modelos de análise do poder: 0 modelo jurídico-discursivo e o modelo da normalização.

Nesse contexto, a lei aparece como uma regra de interdição, de proibição, regra que permite uma separação rigorosa entre o permitido e o proibido, entre o lícito e o ilícito. A lei aparece, assim, como instância que impõe limites e que diz não.

\footnotetext{
${ }^{12}$ Os mecanismos disciplinares são instrumentos destinados à criação de hábitos em torno de práticas e posturas esperadas. Esse tecido de bábitos formados pelos mecanismos disciplinares define a pertença das pessoas a um grupo social. Norma é esse tecido de hábitos (FOUCAULT, 1994, p. 208).
} 
Desse modo, a lei serve de ferramenta para isolar a noção de normalização, para caracterizar o modelo de poder oposto àquele que é o modelo da normalização, marcado pela produção das relações de forças na constituição de objetos, saberes e sujeitos.

Entretanto, é preciso notar que, se no plano conceitual, para Foucault, a lei está atrelada a uma concepção negativa de poder, a uma regra acompanhada de sanções, e portanto às noções de poder soberano e monarquia jurídica, por outro lado, no plano que privilegia as práticas, a lei e os procedimentos de normalização não podem ser pensados de forma independente (FONSECA, 2002, p. 95).

Portanto, os dois planos, embora se oponham conceitualmente, não são contraditórios, mas se complementam no plano das práticas. É justamente no campo das práticas que Foucault propõe uma ruptura conceitual, i.e., uma ampliação daquilo que comumente se tem chamado forma da lei. Ampliação esta que remete para algo muito além de uma estrutura rígida, caracterizada por um comando e uma sanção. Trata-se da noção de ilegalismo proposta por Foucault.

\section{Norma E ILEGALISMO}

0 termo ilegalismo (illégalismes) é uma expressão utilizada por Foucault em Vigiar e Punir e em outros textos e entrevistas (FOUCAULT, 1998, p. 98-99; 1994, p. 469, 744-745, 729-730), termo esse traduzido como ilegalidade nas versões em português. Embora as expressões sejam aparentemente utilizadas com o mesmo sentido, o fato de illégalisme não ser de uso corrente no francês aponta para a intenção de Foucault em marcar uma especificidade não encontrada na expressão mais corrente illegalité.

A noção de ilegalismo encerra um certo regime funcional de atos considerados ilegais no interior de uma dada legislação em vigor e no interior de uma determinada sociedade. A idéia que está ligada à noção de ilegalismo é aquela de gestão de um certo número de ilegalidades ou irregularidades que, considerada (a gestão) em conjunto, representa em si mesma uma certa regularidade. É este sentido que pode ser percebido em Vigiar e Punir e no curso de 1973, em que Foucault analisa as transformações dos ilegalismos nos séculos XVIII e XIX.

Em entrevista com R. Droit, publicada com o título Des Supplices aux Cellules (1994, p. 716-720), Foucault comenta: 
O ilegalismo não é um acidente, uma imperfeição mais ou menos inevitável. É um elemento absolutamente positivo do funcionamento social, cujo papel está previsto na estratégia geral da sociedade. Todo dispositivo legislativo dispõe espaços protegidos e aproveitáveis em que a lei pode ser violada, outros em que pode ser ignorada, outros, enfim, em que as infrações são sancionadas. (...) Ao final de contas, diria que a lei não é feita para impedir tal ou tal tipo de comportamento, mas para diferenciar as maneiras de se fazer circular a própria lei (grifos nossos).

Em tais comentários, bem se vê que a noção de ilegalismo envolve mais do que uma simples prática de um ato ilegal, uma ilegalidade. 0 que está em jogo é um certo regime de práticas consideradas ilegais, em função de um conjunto de elementos extrajurídicos (econômicos e sociais), ainda que os limites em que tal regime se dê tenha uma referência essencial à própria lei, uma vez que esta diferenciaria previamente zonas de rigor e de abrandamento repressivos em função das maneiras pelas quais ela mesma circula.

Pode-se dizer, portanto, que os ilegalismos circulam entre o domínio formalizado da lei e os domínios não formalizados que constituem as práticas de ordem econômica e social.

Para Pierre Lascoumes, em seu artigo "Lillégalisme, outil d'analyse", o conceito de ilegalismo introduzido por Foucault não designa apenas um certo tipo de comportamento transgressivo das normas postas, mas remete sobretudo a um "conjunto de atividades de diferenciação, de categorização, de hierarquização e de gestão social das condutas definidas como indisciplinadas" (LASCOUMES, 1996, p. 78).

Segundo esse autor, o conceito de ilegalismo teria permitido a Foucault realizar um triplo movimento: Primeiro, uma ruptura conceitual, na medida em que permitiu ultrapassar as categorias jurídicas penais tradicionais de infração e acusação e ultrapassar a noção de delinqüência tal qual aparece na criminologia.

A superação dessas noções tradicionais se daria pela denúncia da falsa neutralidade das categorias jurídicas que representam a ordem e a desordem como fatores históricos estáveis e universais. Dar-se-ia também pelo ataque à falsa neutralidade das categorias criminológicas que atribuem a origem dos atos de transgressão social aos determinantes internos do indivíduo.

Um segundo movimento conseguido pela noção de ilegalismo seria de ordem histórica, na medida em que permitiria uma análise dos diferentes regimes 
de práticas sociais que entram em jogo com as regras de direito segunda uma perspectiva fundamentalmente histórica.

Por fim, o conceito de ilegalismo teria permitido a Foucault realizar, ainda que indiretamente, uma reflexão sobre o fato da dominação social.

Portanto, a noção de ilegalismo em Foucault vai além da idéia de um ato realizado contrariamente ao que é disposto por uma lei, a que se poderia adequadamente se chamar de ilegalidade, comporta a idéia de gestão diferencial de certas ilegalidades que adquirem um sentido e um valor específicos no interior de certos meios e situações historicamente determinados.

Tal conceito permite a Foucault, de algum modo, afastar-se de uma concepção demasiadamente rígida da lei. Tal idéia de quebra da fixidez da lei aparece também na entrevista Sur la Sallete, de 1975:

Desde o momento em que uma lei é instaurada, ela proíbe ou condena em um só golpe um certo número de comportamentos. Logo aparece, em torno dela, uma aura de ilegalismos. Ora, esses ilegalismos não são tratados nem reprimidos da mesma maneira pelo sistema penal e pela lei propriamente dita, o que nos permite perguntar se a lei não seria, sob aparência de regra geral, uma maneira de fazer aparecer certos ilegalismos, diferenciados uns dos outros, que vão permitir, por exemplo, o enriquecimento de uns e o empobrecimento de outros, que vão tanto assegurar a tolerância, quanto autorizar a intolerância (1994, p. 723);

Essa concepção peculiar da lei, da sociedade e de suas relações, refere-se a uma espécie de ficção teórica que seria acreditar que as leis teriam sido feitas para serem respeitadas. Ficção esta que nos faria crer que teríamos nos subscrito de uma vez por todas às leis da sociedade a que pertencemos:

A economia dos ilegalismos se reestruturou com o desenvolvimento da sociedade capitalista. 0 ilegalismo dos bens foi separado do ilegalismo dos direitos. Divisão que corresponde a uma oposição de classes, pois, de um lado, 0 ilegalismo mais acessível às classes populares será a dos bens: transferência violenta das propriedades.

De outro lado, a burguesia, então, se reservará o ilegalismo dos direitos: a possibilidade de desviar seus próprios regulamentos e suas próprias leis; de fazer funcionar todo um imenso setor em circulação econômica por um jogo que se desenrola nas margens da legislação - margens previstas por seus silêncios, ou liberadas por uma tolerância de fato. 
E essa grande redistribuição dos ilegalismos se traduzirá até por uma especialização dos circuitos judiciários: Para os ilegalismos de bens - para o roubo - os tribunais ordinários e os castigos; para os ilegalismos de direito - fraudes, evasões fiscais, operações comerciais irregulares - jurisdições especiais com transações, acomodações, multas atenuadas etc.

A burguesia se reservou o campo fecundo do ilegalismo dos Direitos. E ao mesmo tempo em que essa separação se realiza, afirma-se a necessidade de uma vigilância constante que se faça essencialmente sobre os ilegalismos de bens. (FOUCAULT, 1998, p. 326).

\section{CORRUPÇÃO E JOGO DE INTERESSES}

Como foi visto, o cerne do problema está em saber definir os critérios de corrupção na divisão entre o público e o privado, para assim se poder chegar à noção de normalidade, que, como bem demonstram Foucault, Douglas e Canguilhem, é um conceito negativo.

Para Foucault, o normal é um conceito definido em função de seu contrário, isto é, o anormal, o patológico, o criminoso. Portanto, probo seria aquilo que não fosse corrupto.

Mary Douglas, em Purity and Danger, mostra como as noções de impureza e sujeira não têm relação com a natureza das coisas em si mesmas, mas com algo fora-de-lugar:

Sapatos não são sujos em si mesmos, mas tornam-se sujos se forem colocados em cima de uma mesa de jantar; nenhuma comida é suja em si até serem trazidas para o interior de uma privada, por exemplo. Do mesmo modo ocorre com roupas íntimas deixadas em cima das cadeiras da sala de jantar, com objetos que deveriam ficar no interior das casas e são esquecidos fora delas e assim por diante. Em uma palavra, nosso comportamento face à corrupção e sujeira é uma reação que condena qualquer objeto ou idéia fora-de-lugar que possa confundir normas de classificação e separação socialmente construídas (DOUGLAS, 1966, p. 36).

Assim, interesses privados e interesses públicos são ambos perfeitamente limpos eprobos desde que permaneçam em seus devidos lugares. Porém, se houver a contaminação do público pelo privado, políticos e a política em si mesma se tornam sujos e portanto corruptos. 
0 contrário também é igualmente verdadeiro: Se houver a invasão do privado pelo público, quando, por exemplo, o Estado tenta regular comportamentos considerados privados, como a sexualidade e a religião, chega-se às mesmas conclusões negativas com relação à separação categórica entre público e privado.

Canguilhem, por sua vez, vê a questão sob um outro ângulo:

Tem-se destacado quão ambíguos são os vários significados de normal, uma vez que o termo designa, simultaneamente, um fato e um valor atribuído a esse fato pela pessoa que fala, a qual assume a responsabilidade pelo julgamento de valor (emitido sobre o fato). Devemos também salientar o quanto tal ambigüidade é aprofundada pela tradição filosófica a qual sustenta que, assim como toda abstração é um símbolo de uma essência, e toda perfeição a realização de uma substância, uma abstração observável empiricamente assume, na prática, o valor de uma perfeição realizada e de um tipo ideal" (1991, p. 125).

Em conseqüência, poder-se-ia talvez inferir desses pressupostos que 0 conceito moderno de corrupção reproduz uma ênfase normativa de modo apolítico e a-histórico, uma vez que se refere a um sistema de classificação e separação ideal, cuja única referência é a própria regra de separação.

Em outras palavras, não há nenhuma outra fonte explicativa para a lógica ou razão de ser das regras que estabelecem o corrupto e o não-corrupto, o normal e o patológico, a não ser as próprias regras de separação: Assim como porcos ou camarões, de uma perspectiva biológica, não são mais ou menos impuros, assim também o clientelismo ou a propina não são mais ou menos corruptos em relação à natureza dos interesses que tais tipos de atividades articulam.

Por exemplo, por que estabelecer o limite legal de 50 dólares ${ }^{13}$ no valor dos presentes ou prendas que um parlamentar norte-americano pode receber sem violar o Código de Ética política daquele país? Por que 60 ou 80 dólares não cumpririam a mesma função?

A resposta, seguindo os pressupostos de Foucault, Douglas e Canguilhem, é simples: não há separação do corrupto e do não-corrupto sem regras, e não há regras sem separação.

Assim, a única função dos 50 dólares é criar um limite, estabelecer um critério, uma norma que fabrica uma distinção por meio da qual o sujeito se

${ }^{13}$ Cr. US Code of Official Conduct, Gifts.

CORRUPÇÃO E MORTE DA POLÍTICA: ANÁLISE DE UMA PATOLOGIA SOCIAL 
conforma ao que é normal ou patológico, corrupto ou probo em matéria de presentes que podem ou não ser aceitos por políticos norte-americanos.

Porque todos sabem que 0 interesse sempre estará presente nas ações dos indivíduos, há a necessidade de se estabelecerem regras de separação para desvincular a ação política de um parlamentar de qualquer forma de propina ou suborno. Cria-se, para isso, a categoria oficial de lobista: Aquele que, nos Estados Unidos, está legalmente registrado para tal atividade, e garante-se com isso a pureza da separação do público e do privado.

Como corolário de tal separação, nasce o dever de o agente público abstrair de seus interesses privados a fim de agir conforme a ética pública. Daí 0 grande número de regras específicas que indicam o que constitui ganho privado e o que não constitui. Sem tais regras de separação, não seria possível saber o que é corrupção política.

Trata-se, como bem explicou François Ewald ao comentar a idéia de norma em Foucault, de "um princípio de comparação, uma comparabilidade, uma medida comum, que se institui na pura referência de um grupo a si próprio, a partir do momento em que só se relaciona consigo mesmo, sem exterioridade, sem verticalidade" (EWALD, 1993, p. 86).

Nosso Código de Ética e Decoro Parlamentar, por exemplo, veda ao senador a "percepção de vantagens indevidas, tais como doações, benefícios ou cortesias de empresas, grupos econômicos ou autoridades públicas, ressalvados os brindes sem valor econômico"14.

Mas porque alguém, não sendo nem parente nem amigo, daria a algum parlamentar "um brinde sem valor econômico" ou contribuiria para sua de campanha política a não ser como forma de apoio pelas ações que ele realizou ou possivelmente realizará?

Dado que é impossível remover os interesses privados da ação política ou da administração pública, foi criada a ficção jurídica do interesse público por meio de um conjunto de regras, rituais e gestos performativos destinados a garantir a pureza do domínio público. A reificação que ocorre aqui é a necessidade de rearticular as relações sociais por meio do Estado, ao qual compete organizar e regulamentar conflitos de interesses cada vez maiores e mais complexos.

Em outras palavras, torna-se imperativo, para o processo de legitimação do Estado burguês, fazer com que o jogo de interesses privados atuem como se

${ }^{14}$ Código de Ética e Decoro Parlamentar, art. 4, II. 
fossem públicos. 0 agente público precisa agir como se fosse destituído de qualquer interesse privado para se conformar à ética pública.

Ora, os interesses privados são imanentes ao exercício da política contemporânea: são os interesses privados que financiam as campanhas políticas; uma vez eleitos, os políticos lutam pelos interesses de seus constituintes e não raras vezes pelos seus próprios.

\section{MORTE DA POLÍTICA?}

Todos sabemos que uma separação total e substantiva de qualquer forma de interesse privado na esfera pública representaria a morte da política tal qual praticada hoje em dia.

Como bem explicitou José Arthur Giannotti,

Toda norma, para poder funcionar, implica uma série de relaxamento em torno dela, uma dose de indefinição de seus casos. Para mostrar isso, Wittgenstein lembra que para um embolo funcionar não pode estar inteiramente ajustado à camisa, pois um ajustamento prefeito impediria o movimento.

Em outras palavras, a corrupção é condição da liberdade humana: você não encontra formigas corruptas no formigueiro. É a liberdade em relação à norma que nos permite sermos corruptos. Trata-se de uma possibilidade ligada ao fato de que o homem não é exclusivamente um ser natural, mas uma forma específica de infração. (...)

Para que possamos ser livres é preciso conservar a viabilidade de quebrar a norma. Um país onde as instituições vigilantes estreitam de tal maneira as possibilidades de corrupção é um país em que a liberdade perece. Esse jogo é fundamental, porque implica uma relação pública com a norma que não pode ser de intolerância. Noutras palavras, não pode haver uma política de governo ou de oposição que tenha como bandeira unicamente ser contra a corrupção (2001, p. 9-10).

\section{CONCLUSÃo}

Poderíamos agora concluir esta análise confrontando a bipolaridade do conceito moderno de corrupção (interesse público x interesse privado ou legalidade $\mathrm{x}$ ilegalidade) com a bipolaridade do modelo jurídico-discursivo de poder descrito por Foucault em suas versões, a marxista (opressão e repressão) e a liberal (lei e ordem). 
Em outros termos, a abordagem do problema da corrupção pelo modelo jurídico-discursivo em sua versão liberal toma, como pressuposto, duas ficções teóricas: A primeira diz respeito à separação categórica entre interesses públicos e privados; a segunda baseia-se em uma suposta neutralidade das categorias jurídicas em virtude da qual a lei seria igual para todos, sendo os atos de transgressão social tributados aos determinantes internos do indivíduo.

A essa visão, Foucault contrapõe a noção de gestão diferencial dos ilegalismos, isto é, o conjunto de atividades de diferenciação, de categorização, de hierarquização e de gestão social das condutas definidas como indisciplinadas, que possibilita uma maior ou menor tolerância em relação ao cumprimento da lei, permitindo o enriquecimento de uns e o empobrecimento de muitos, por meio do que ele chama de economia dos ilegalismos. Ao contrário da abordagem law and order que vê no poder político o veículo da instauração da paz social e da ordem, por meio da lei, Em defesa da sociedade procura pensar o poder enquanto guerra perpétua.

Com relação à abordagem marxista do problema da corrupção, podemos dizer que há uma tradição no pensamento socialista, de Proudhon a Marx, que procura fazer da denúncia à corrupção uma denúncia à política em si mesma. Tolera-se a atividade política, mas com a perspectiva de que seja ultrapassada por uma sociedade transparente (kommunistische Wesen), em que impera a administração racional das coisas.

Em oposição ao marxismo, que considera a corrupção e o poder político como modos de opressão organizada exercida pelas classes dominantes, A vontade de saber procura mostrar que o poder não reprime nem interdita, mas incita e produz. Portanto, para Foucault, a principal atuação do poder não é a opressão, mas a produção do homem "útil e dócil" (FOUCAULT, 1979, p. 20).

A nosso ver, o que se verifica em ambas as abordagens, seja a liberal seja a marxista, é uma tentativa peculiar de se negar a política por meio da camisa de força do moralismo político, em suas versões utópico-marxista e ético-burguês.

Talvez por isso, a história tem se mostrado irônica em relação aos surtos de moralismo político. Na Itália, o sistema político do pós-guerra desmoronou, num processo em que a luta contra a corrupção era uma questão central. Mais recentemente, a longa e dolorosa operação mani puliti (mãos limpas), que desbaratou parte do crime organizado naquele país, ironicamente resultou, há alguns anos, na eleição para primeiro-ministro do capo Berlusconi. 
No Brasil, o moralismo político da velha UDN acabou naufragando no mesmo pântano de corrupção que seus opositores de esquerda. De modo análogo, o sempre vigilante "baluarte" da ética pública, o Partido dos Trabalhadores, vê-se atualmente enlameado por toda sorte de escândalos políticos.

Política é condição humana, que implica liberdade de projetar sombras e conviver com os paradoxos da vida. Sem isso em mente, poderemos estar abrindo as portas para 0 totalitarismo.

\section{REFERÊNCIAS}

BRATSIS, Peter. Everyday Life and the State. London: Paradigm Publishers, 2006.

CANGUILHEM, Georges. The Normal and the Pathological. New York: Zone Books, 1991.

CÓDIG0 de Ética e Decoro Parlamentar do Senado Federal (Resolução nº 20 de 1993).

DAU, Sandro. A Negatividade e a Positividade do Poder em Michel Foucault. Rio de Janeiro: UNIPAC, 2004.

DOUGLAS, Mary. Purity and Danger. London: Routledge, 1966.

EWALD, François. Foucault: a norma e o direito. Lisboa: Veja, 1993.

FONSECA, Márcio Alves da. Michel Foucault e o Direito. São Paulo: Max Limonad, 2000.

FOUCAULT, Michel. Em Defesa da Sociedade. São Paulo: Martins Fontes, 2000. . Vigiar e Punir. Petrópolis: Vozes, 1999.

. La Societé Punitive. (Dits et Écris). Paris, Gallimard, 1994. . Sécurité, Territoire, Population; Naissance de la Biopolitique. Paris, Gallimard, 1979. . Naissance de la biopolitique. Paris, Gallimard, 1979. . A Microfísica do Poder. Rio de Janeiro: Graal, 1979. . La gouvernementalité. (Dits et Écris). Paris, Gallimard, 1994. 
- Lillégalisme et l'art de puni. (Dits et Écris). Paris, Gallimard, 1994. -L'extension sociale de la norme. (Dits et Écris). Paris, Gallimard, 1994. 1994. . Le pouvoir, une bête magnifique. (Dits et Écris). Paris, Gallimard, _. A verdade e as formas jurídicas. Rio de Janeiro: NAU, 1996.

__ História da Loucura. São Paulo: Editora Perspectiva, 2002.

_. A vontade de saber. In: História da sexualidade. Rio de Janeiro: Graal, 1997. . Surveiller et Punir. Paris: Gallimard, 1998.

GAIO, André Moysés. 0 Estado Delinqüente: uma nova modalidade de crime? Salvador: Especiarias, 2007.

GIANNOTTI, José Arthur. Debate sobre corrupção. São Paulo: Novos Estudos, 2001.

HEIDENHEIMER, Arnold J.; JOHNSTON, Michael; LEvINE, Victor T. Political Corruption: A Handbook. New Jerssey: Transaction, 1989.

HIRSCHMAN, Albert. The Passions and the Interests. New Jersey: Princeton University Press, 1977.

HUNTINGTON, Samuel P. Political Order in Changing Societies. New Haven: Yale University Press, 1968. 